\title{
Spanish trauma icu registry (RETRAUCl). Final results of the pilot phase
}

\author{
M Chico-Fernández ${ }^{1}$, JA Llompart-Pou ${ }^{2 *}$, F Alberdi-Odriozolo ${ }^{3}$, F Guerrero-López ${ }^{4}$, M Sánchez-Casado ${ }^{5}$, \\ MD Mayor-García ${ }^{6}$, J Egea-Guerrero ${ }^{7}$, JF Fernández-Ortega ${ }^{8}$, A Bueno-González ${ }^{9}$, J González-Robledo ${ }^{10}$, \\ L Servià-Goixart ${ }^{11}$, J Roldán-Ramírez ${ }^{12}$, MÁ Ballesteros-Sanz ${ }^{13}$, E Tejerina-Álvarez $^{14}$, \\ GT Trauma y Neurointensivismo SEMICYUC
}

From ESICM LIVES 2015

Berlin, Germany. 3-7 October 2015

\section{Introduction}

Trauma registries are essential to understand the health care reality and underscore potential areas of improvement in trauma patient management.

\section{Objectives}

To present a real picture of the epidemiology of severe trauma and its related attention in Spanish intensive care units (ICUs) through the final results of the pilot phase of the Spanish trauma ICU registry (RETRAUCI).

\section{Methods}

Prospective multicenter registry of patients with trauma admitted in 13 Spanish ICUs. We evaluated epidemiology, out-of-hospital attention, registry of injuries, resources utilization, complications and outcome.

\section{Results}

We evaluated 2242 patients. Mean age $47.1 \pm 19.02$ years. Male 79\%. Blunt trauma 93.9\%. Injury Severity Score 22.2 \pm 12.1 , Revised Trauma Score $6.7 \pm 1.6$. Non-intentional in $84.4 \%$, most common causes for trauma were road traffic accidents followed by pedestrian and high-energy falls. Up to $12.4 \%$ were taking antiplatelets or anticoagulants. Close to $28 \%$ had suspected or confirmed toxic influence in trauma. Up to $31.5 \%$ required out-of-hospital artificial airway. Time between trauma and ICU admission was $4.7 \pm 5.3$ hours. At ICU admission, $68.5 \%$ remained hemodinamically stable. Twenty-six percent received blood transfusion within 6 hours of ICU admission. Brain and chest injuries were predominant. Complications occurred frequently: trauma-induced coagulopathy in $32.1 \%$, rhabdomyolysis $11.1 \%$, early and late MOF $10.9 \%$ and $15.7 \%$ respectively, ARDS $23.4 \%$, renal failure $14.7 \%$ and nosocomial infection $32.3 \%$. Intracranial pressure was monitored invasively in $21 \%$. Of them $65.8 \%$ presented intracranial hypertension. Mechanical ventilation was used in $69.5 \%$ of the patients (mean $8.2 \pm 9.9$ days), of which $24.9 \%$ finally required a tracheostomy ICU and hospital length of stay were $10.1 \pm 12.8$ and $16.0 \pm 20.8$ days respectively. ICU mortality was UCI $12.3 \%$ (273 patients). In-hospital after ICU mortality was $3.7 \%$. Of note, up to $11.6 \%$ were transferred to another ICU.

\section{Conclusions}

The pilot phase of the RETRAUCI shows a real and precise picture of the epidemiology and attention of severe trauma patients admitted in Spanish ICUs.

\section{Grant Acknowledgment}

Fundación Mutua Madrileña 


\section{References}

1. Chico Fernández M, García Fuentes C, Guerrero López F: Trauma registries: a health priority, a strategic project for the SEMICYUC. Med Intensiva 2013, 37:284-9.

2. Pino Sánchez Fl, Ballesteros Sanz MA, Cordero Lorenzana L, Guerrero López F, Grupo de Trabajo de Trauma y Neurointensivismo de SEMICYUC: Quality of trauma care and trauma registries. Med Intensiva 2015, 39:114-123.

doi:10.1186/2197-425X-3-S1-A377

Cite this article as: Chico-Fernández et al.: Spanish trauma icu registry (RETRAUCI). Final results of the pilot phase. Intensive Care Medicine Experimental 2015 3(Suppl 1):A377.

\section{Submit your manuscript to a SpringerOpen ${ }^{\mathcal{O}}$ journal and benefit from:}

- Convenient online submission

- Rigorous peer review

- Immediate publication on acceptance

- Open access: articles freely available online

- High visibility within the field

- Retaining the copyright to your article

Submit your next manuscript at $\gg$ springeropen.com 